Potravinarstvo Slovak Journal of Food Sciences

vol. 15, 2021, p. 33-39

https://doi.org/10.5219/1435

Received: 11 July 2020. Accepted: 15 January 2021.

Available online: 28 January 2021 at www.potravinarstvo.com

(C) 2021 Potravinarstvo Slovak Journal of Food Sciences, License: CC BY 3.0

ISSN 1337-0960 (online)

\title{
THE CONTRIBUTION OF PROTEINS, FATS, CARBOHYDRATES, AND ALCOHOL TO THE TOTAL ENERGY VALUE OF THE DIET: A CROSS-SECTIONAL STUDY
}

\author{
Alexey Galchenko, Elizaveta Sidorova, Artem Barinov, Nikita Titov, Andrew Skalny
}

\begin{abstract}
While eating, people receive energy, as well as the necessary nutrients. However, different food products contain different amounts of macro- and micronutrients, so their consumption can vary significantly depending on eating habits. The diets of 105 people, first-year students of the Peoples` Friendship University of Russia from six different regions of the Earth: CIS countries; Latin America; Central and South Africa; North Africa, the Middle East, and Central Asia; Central and South Asia; Iran and Azerbaijan - were analyzed. Nutrition was evaluated by the frequency method. The median calorie intake among all examined was $2756 \mathrm{kcal}$ per day. At the same time, the proportion of proteins from the total calorie content was $15.3 \%$, from fats $-37.5 \%$, from carbohydrates $-47.1 \%$, from alcohol $-0.5 \%$. It was not possible to detect significant differences in the consumption of macronutrients or their contribution to the energy value of the diet between the regions. The exception was ethanol consumption: students coming from Central and South Africa consumed significantly more alcoholic drinks compared to students from Russia, Ukraine, and Moldova. Due to the extremely high level of dispersion within each of the studied groups, it was not possible to detect significant differences in the consumption of macronutrients, depending on the region of origin of the student. That is, intra-group differences turned out to be significantly more than inter-group differences. At the same time, the share of macronutrients in ensuring the total calorie content of the diet in this study turned out to be close to the data obtained in large cities of other countries and significantly differed from the results of the assessment of diets of rural residents. Probably, the student's nutrition is formed largely under the influence of the urban environment and individual taste preferences; ethnic and cultural affiliation plays a much smaller role.
\end{abstract}

Keywords: calorie content; energy substrates; macronutrients; regional features; ethnicity

\section{INTRODUCTION}

During a meal, a person receives energy, as well as the necessary nutrients. Proteins, fats, and carbohydrates are macronutrients. Each of them performs certain functions. However, different foods contain different amounts of them, so their consumption may vary depending on food predilections and habits (Tutelyan, 2012).

Proteins are one of the main components of the diet. During digestion, they break down to amino acids, which are absorbed in the small intestine. In the future, amino acids are involved in the resynthesis of the body's peptides and proteins. Proteins are part of all the basic structures of cells, tissues, and organs, perform enzymatic functions, participate in the transport of substances, are the basis of protein hormones, and carry out intercellular signaling. Amino acids are also involved in the synthesis of protein derivatives - neurotransmitters and hormones (Galchenko, Morozova and Zaletova, 2017). Another function of amino acids is that they act as nitrogen donors in the synthesis of nitrogen-containing compounds of a nonprotein nature, such as nucleotides, heme, creatine, etc.
Amino acid metabolism usually begins with transamination or deamination reactions, after which either new amino acids or $\alpha$-keto-acids are formed, or $\alpha$-ketoacids and an amine residue. Then it goes into the ornithine cycle, which regulates the nitrogen balance of the body. The main product of this cycle is urea. Nitrogen-free amino acid residues are converted into pyruvate, acetylCoA, alpha-ketoglutarate, succinyl-CoA, and fumarate, which enter the Krebs cycle, and subsequently into the electron transfer chain, which ends with the synthesis of ATP. With a decrease in the level of glucose in the bloodstream, one of the derivatives of asparagine and aspartic acid, oxaloacetate, will participate in glucose resynthesis - gluconeogenesis (Severin, 2011a).

Fats form the basis of the cell membrane, are the main source of carbon and hydrogen atoms, and perform energy and signal functions (Rustan and Drevon, 2005). Also, lipids act as thermal insulation and are the precursors of bile acids and steroids. Lipid metabolism begins with emulsification by bile acids. After this, the surface area of the fat droplets increases many times, and they undergo 
hydrolysis. Hydrolysis products - fatty acids, monoacylglycerols, and diacylglycerols - as well as bile acids, cholesterol, and hydrophobic vitamins, form mixed micelles (Severin, 2011b). They are absorbed into the cells of the small intestine mucosa, where they break down into the main components. Fatty acids can be deposited, form the structural components of cells, and also oxidize to acetyl-CoA and enter the citrate cycle. Ketone bodies, phospholipids, triacylglycerol, eicosanoids, and cholesterol are also formed from fatty acids. Further, cholesterol is involved in the synthesis of bile acids, esters, and steroids (Wakil, 1962).

The main function of carbohydrates is energy supply. They participate in the synthesis of fatty acids, amino acids, nucleotides, which are part of the glycocalyx, which acts as cellular receptors, antigens, and also participates in parietal digestion and transport of substances. Carbohydrates can also be stored as glycogen. The main monomer of carbohydrates in humans is glucose. Its metabolism begins with the formation of glucose-6phosphate, which subsequently participates in various processes of synthesis and decomposition. The breakdown of glucose-6-phosphate, glycolysis, can occur both in the presence of oxygen and in its absence. Different products form depending on this. So, with a lack of oxygen, pyruvate is converted into lactate, which is transposed into muscle or liver. In the presence of oxygen, pyruvate is converted to acetyl-CoA in the pyruvate dehydrogenase complex. Then acetyl-CoA enters the citrate cycle. The result is the release of energy as ATP and carbon dioxide and water formation. The reverse route from pyruvate to glucose is also possible - gluconeogenesis. It provides maintenance of blood glucose during fasting and physical exertion. Also, glucose-6-phosphate can enter the pentose phosphate pathway, which ends with the formation of hexoses and pentoses. Some pentoses may also be part of nucleotides. Other monosaccharides and heteropolysaccharides, lipids, amino acids, and glycerol can also be formed from glucose (Figure 1) (Severin, 2011c).

Ethanol can be synthesized in the body or ingested with food. Exogenous ethanol is rapidly absorbed in the stomach and small intestine. Ethanol metabolism mainly occurs in the liver and begins in the oral mucosa. Ethanol is subsequently oxidized by the action of alcohol dehydrogenase and acetaldehyde dehydrogenase to acetaldehyde and acetic acid, respectively. Next, acetic acid is converted to acetyl-CoA. It, in turn, is oxidized in the citrate cycle to carbon dioxide, and with its excess is used for the synthesis of fatty acids, fat, and cholesterol. Ethanol as an amphiphilic substance can enhance the permeability of the blood-brain barrier, disrupt the structure and functions of cell membranes, and cause a change in metabolism in almost all organs. So, as a result of ethanol catabolism, the number of NADH increases, which leads to increased lactate formation and slows down gluconeogenesis (Severin, 2011d).

Thus, the metabolism of all macronutrients is closely related. All of them, to one degree or another, are capable of mutual transformations and are predecessors of each other. Synergy concerning basic functions (primarily energy) leads to the fact that the ratio of incoming macronutrients with food can vary significantly, without leading to immediate clinical manifestations of food imbalance. The general scheme of interconversion of macronutrients is presented in Figure 1.

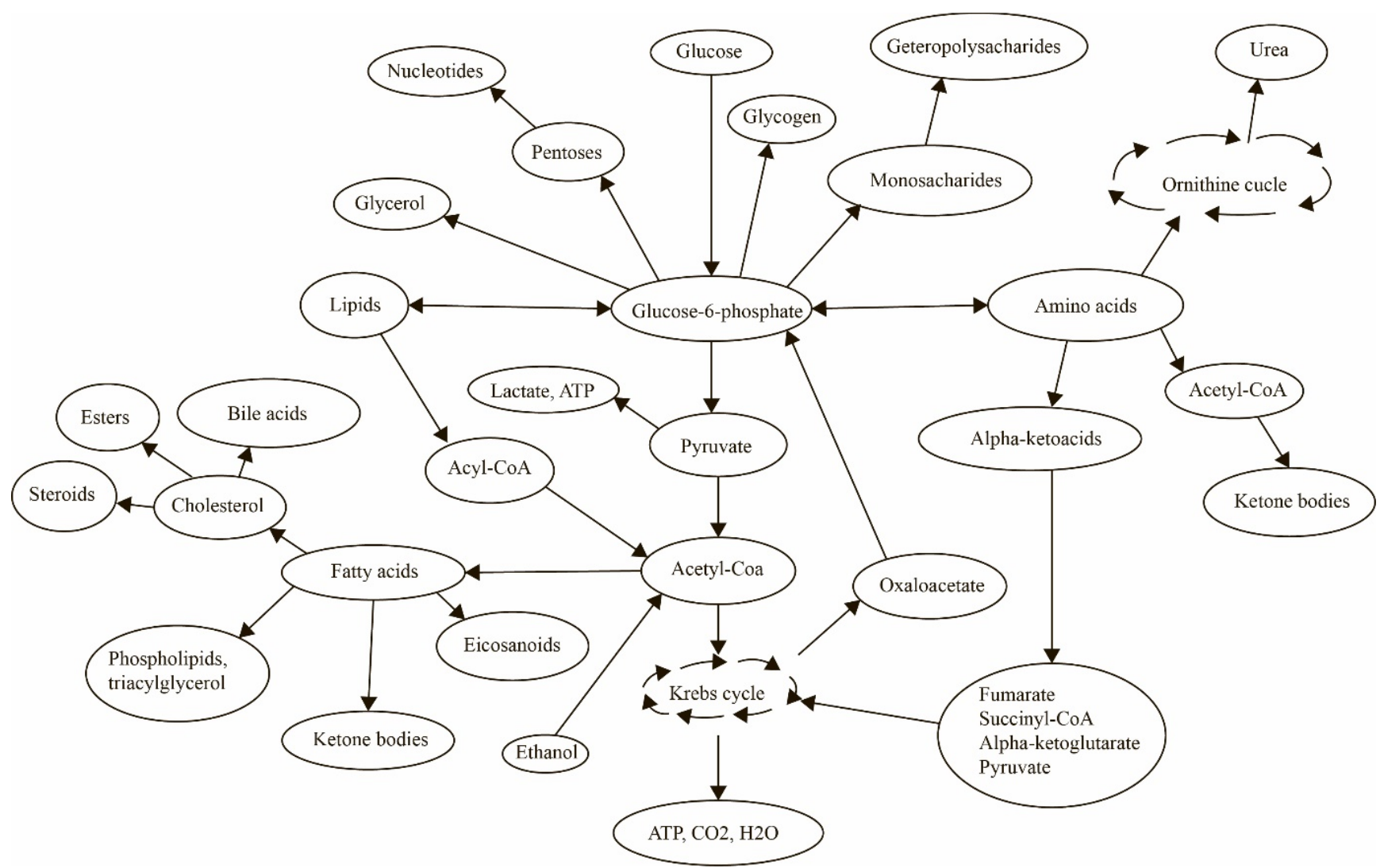

Figure 1 The general scheme of macronutrient metabolism. 


\section{Scientific hypothesis}

The objective of the study was to understand how national and cultural traditions influence the nature of people's nutrition. Besides, even with comparable caloric intake, the contribution of various macronutrients to the total energy value can vary significantly depending on the products that make up the diet.

\section{MATERIAL AND METHODOLOGY}

In this study, 105 people (71 women and 34 men), firstyear students of the Peoples' Friendship University of Russia from 33 countries of North and South America, Africa, Europe, and Asia, were examined. The subjects were divided into six groups based on the previous region of residence: 18 people from South, Southeast Asia, Mongolia, and China, 4 people from Latin America, 12 people from North Africa, the Middle East, Central Asia, and Afghanistan, 14 people from South and Equatorial Africa, 4 people from Iran and Azerbaijan, and 54 people from Russia, Ukraine, and Moldova. The age of the subjects was from 20 to 51 years $(\mathrm{Me}=23$ years).

Evaluation of the actual nutrition was carried out by the method of frequency analysis with Nutrilogic software ("Nutrilogic" LLC, Ryazan, Russia). Food consumption for 3 - 6 months was taken into account. The interview was fully structured. Everyone was asked to recall the features of their diet and the frequency of consumption of main dishes and products. Subjects were suggested to estimate the intake of each group of products separately. The same situation was with the evaluation of food consumption frequency: people had to choose one of the given variants. Photographic measures were used for estimating the amount of food. There were color images of portions of a known weight of different products and dishes included in the Nutrilogic program package. The life-size portions of different weights were presented in photographs on the monitor screen, and the subject determined how much his average portion was comparable with the shown one. Data on the chemical composition of the foods in Nutrilogic is mainly based on the Tutelyan handbook (Tutelyan, 2012).

The fractions of proteins, fats, and carbohydrates in the total calorie intake were calculated based on the fact that

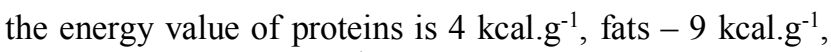
carbohydrates $-4 \mathrm{kcal}^{-1} \mathrm{~g}^{-1}$ (Norms of physiological needs, 2009b), ethanol - $7 \mathrm{kcal}^{-1}{ }^{-1}$ (Kolman and Rum, 2000). The mass of ethanol consumed was calculated via the formula $\mathrm{m}=\mathrm{V} * \rho$, where $\rho$ is the density of ethanol equal to 0.79 g.mL $\mathrm{mL}^{-1}$ (Chemical Encyclopedia, 1999).

\section{Statistical analysis}

Statistical data processing was carried out using the SPSS 23 application software package. Analysis of the research results was carried out using descriptive statistics. The sample was not representative; accordingly, the data are presented as medians and quartiles. The differences between the two independent groups were determined by the Mann-Whitney criterion. The differences between all groups were determined by the Kruskal-Wallis test. To determine significance in all tests $p<0.05$.

\section{RESULTS AND DISCUSSION}

The median caloric value of the diet among all groups was $2756 \mathrm{kcal}$ per day, and the intake of proteins, fats, carbohydrates, and alcohol was $101 \mathrm{~g}, 109.6 \mathrm{~g}, 311.8 \mathrm{~g}$, and $2.6 \mathrm{ml}$, respectively. The values within the groups varied significantly, the difference between the values of 25 and 75 percentiles in most cases was more than

Table 1 Consumption of macronutrients and energy value of the diet in groups.

\begin{tabular}{|c|c|c|c|c|c|}
\hline Region & $\begin{array}{c}\text { Energy, kcal, } \\
\text { median } \\
\text { (percentiles } \\
\mathbf{2 5 \%} ; \mathbf{7 5 \%} \text { ) }\end{array}$ & $\begin{array}{l}\text { Proteins, } g \\
\text { median } \\
\text { (percentiles } \\
25 \% ; 75 \%)\end{array}$ & $\begin{array}{c}\begin{array}{c}\text { Fats, } g \\
\text { median } \\
\text { (percentiles }\end{array} \\
25 \% ; 75 \%)\end{array}$ & $\begin{array}{c}\text { Carbohydrates, } \\
\text { g } \\
\text { median } \\
\text { (percentiles } \\
25 \% ; 75 \%)\end{array}$ & $\begin{array}{c}\text { Alcohol, ml } \\
\text { median } \\
\text { (percentiles } \\
25 \% ; 75 \%)\end{array}$ \\
\hline $\begin{array}{l}\text { South and Southeast Asia, } \\
\text { Mongolia and China }\end{array}$ & $\begin{array}{c}2300 \\
(1660 ; 3907)\end{array}$ & $\begin{array}{c}78.4 \\
(61.3 ; 155.6)\end{array}$ & $\begin{array}{c}99.3 \\
(70.8 ; 159.08)\end{array}$ & $\begin{array}{c}287.9 \\
(205.5 ; 454.9)\end{array}$ & $\begin{array}{c}1.7 \\
(0 ; 14.7)\end{array}$ \\
\hline Latin America & $\begin{array}{c}2624 \\
(976 ; 5852)\end{array}$ & $\begin{array}{c}102.7 \\
(37.3 ; 178.9) \\
\end{array}$ & $\begin{array}{c}109.2 \\
(38.4 ; 270.4) \\
\end{array}$ & $\begin{array}{c}307.5(125.8 ; \\
698.2)\end{array}$ & $\begin{array}{c}6.5 \\
(0 ; 11.6) \\
\end{array}$ \\
\hline $\begin{array}{l}\text { North Africa, Middle East, } \\
\text { Central Asia, and } \\
\text { Afghanistan }\end{array}$ & $\begin{array}{c}2722 \\
(1704 ; 3808)\end{array}$ & $\begin{array}{c}116.3 \\
(61.9 ; 174.1)\end{array}$ & $\begin{array}{c}104.2 \\
(75.5 ; 149.0)\end{array}$ & $\begin{array}{l}304.8(186.2 \\
\quad 435.8)\end{array}$ & $\begin{array}{c}6.6 \\
(1.1 ; 14.9)\end{array}$ \\
\hline $\begin{array}{l}\text { South and Equatorial } \\
\text { Africa }\end{array}$ & $\begin{array}{c}2746 \\
(1911 ; 4045) \\
\end{array}$ & $\begin{array}{c}108.7 \\
(74.6 ; 166.1) \\
\end{array}$ & $\begin{array}{c}102.2 \\
(79.1 ; 155.8) \\
\end{array}$ & $\begin{array}{c}343.25 \\
(196.7 ; 446.6) \\
\end{array}$ & $\begin{array}{c}15.4 \\
(3.95 ; 28.5)^{*} \\
\end{array}$ \\
\hline Iran and Azerbaijan & $\begin{array}{c}3305 \\
(1634 ; 5572)\end{array}$ & $\begin{array}{c}145.9 \\
(57.9 ; 249.9)\end{array}$ & $\begin{array}{c}137.8 \\
(76.4 ; 259.1)\end{array}$ & $\begin{array}{c}373.25 \\
(164.9 ; 563.1) \\
\end{array}$ & $\begin{array}{c}4.1 \\
(0 ; 9.3) \\
\end{array}$ \\
\hline $\begin{array}{l}\text { Russia, Moldova and } \\
\text { Ukraine }\end{array}$ & $\begin{array}{c}2841 \\
(2080 ; 3769)\end{array}$ & $\begin{array}{c}100.7 \\
(76.4 ; 143.6)\end{array}$ & $\begin{array}{c}116.8 \\
(85.8 ; 166.4)\end{array}$ & $\begin{array}{c}349.9(203.8 \\
490.4)\end{array}$ & $\begin{array}{c}1.3 \\
(0 ; 8.4)^{*}\end{array}$ \\
\hline All regions & $\begin{array}{c}2716 \\
(1970 ; 3910)\end{array}$ & $\begin{array}{c}101.0 \\
(73.6 ; 153.2)\end{array}$ & $\begin{array}{c}109.6 \\
(77.2 ; 163.4)\end{array}$ & $\begin{array}{c}311.8(206.2 \\
464.9)\end{array}$ & $\begin{array}{c}2.6 \\
(0 ; 11.5)\end{array}$ \\
\hline
\end{tabular}

Note: $*-p<0.05$. 
Table 2 The share of various macronutrients in the total calorie intake.

\begin{tabular}{|c|c|c|c|c|}
\hline Region & Proteins, \% & Fats, $\%$ & Carbohydrates, \% & Alcohol, \% \\
\hline $\begin{array}{l}\text { South and Southeast Asia, } \\
\text { Mongolia and China }\end{array}$ & $13.9 \%$ & $40.1 \%$ & $51.3 \%$ & $0.4 \%$ \\
\hline Latin America & $16.1 \%$ & $38.7 \%$ & $48.0 \%$ & $1.4 \%$ \\
\hline $\begin{array}{l}\text { North Africa, Middle East, } \\
\text { Central Asia and } \\
\text { Afghanistan }\end{array}$ & $17.5 \%$ & $35.6 \%$ & $45.9 \%$ & $1.4 \%$ \\
\hline $\begin{array}{l}\text { South and Equatorial } \\
\text { Africa }\end{array}$ & $16.2 \%$ & $34.6 \%$ & $51.3 \%$ & $3.1 \% *$ \\
\hline Iran and Azerbaijan & $18.1 \%$ & $38.7 \%$ & $46.3 \%$ & $0.7 \%$ \\
\hline $\begin{array}{l}\text { Russia, Moldova and } \\
\text { Ukraine }\end{array}$ & $14.5 \%$ & $38.1 \%$ & $51.6 \%$ & $0.2 \% *$ \\
\hline All regions & $15.3 \%$ & $37.5 \%$ & $47.1 \%$ & $0.5 \%$ \\
\hline
\end{tabular}

twofold. Such a high dispersion of values did not allow us to identify significant differences in the consumption of macronutrients in multiple comparisons (Kruskal-Wallace test) and even in pairwise comparisons (Mann-Whitney test), despite considerable differences in median indices between regions. The exception was alcohol consumption for the CIS countries and South and Equatorial Africa: the latter consumed much more ethanol. Table 1 shows the daily consumption of macronutrients and calorie intake.

The contribution of proteins to the energy value of the diet in all regions (medians) was $15.3 \%$, of fats $-37.5 \%$, of carbohydrates $-47.1 \%$, of alcohol $-0.5 \%$. Similarly to the absolute indicators of macronutrient consumption, when comparing their shares in the total calorie content, it was not possible to identify significant differences (except for the consumption of the contribution of alcohol between students from Equatorial and South Africa and the CIS countries).

Table 2 presents the distribution of caloric intake by macronutrients among groups of students.

In the Russian Federation, the recommended dietary allowances for macro- and micronutrients, as well as for the energy value of the daily diet are presented in the Norms of physiological needs (2009a). According to the document, for the adult population, protein intake should be $11-12 \%$ of the total calorie content, fats $-30-33 \%$, carbohydrates - 58\%. The examined students predominantly consumed more proteins and fats, abundantly contained in fast food, at the expense of a decrease in the proportion of carbohydrates.

Only about a quarter of the examined students consumed the recommended in Russia amounts of macronutrients (proteins - $65-117 \mathrm{~g} /$ day $(\mathrm{m}) 58-87 \mathrm{~g} /$ day (f); fats $70-154 \mathrm{~g} /$ day (m) $60-102 \mathrm{~g} /$ day (f); carbohydrates 257 - $586 \mathrm{~g}$ /day) (Norms of physiological needs, 2009b). This once again emphasizes the degree of intra-group differences.

Similar studies have been conducted in other countries. So, Matthys et al. (2003) found that among adolescents in Belgium on average $35.7 \%$ of the calorie intake was in fats, $49 \%$ - in carbohydrates. In adolescents in Spain, the proportion of protein in the caloric content of the diet was
$17.8 \%$, fats - 34\%, carbohydrates - 46.4\% (LopezSobaler et al., 2019). According to other data, the calorie content of the diets of Spanish children consisted of $16.5 \%$ of proteins, $36.5 \%$ of fats, $45.4 \%$ of carbohydrates (Madrigal et al., 2020). According to Merkiel and Chalcarz (2016), children in Poland received $12 \%$ of their energy from protein, $33.4 \%$ from fats, and $54.1 \%$ from carbohydrates. In the United States, children's diets were $15 \%$ protein energy, $31 \%$ fat, and $53 \%$ carbohydrate (Martinez et al., 2017). At the same time, the diets of North American adults included 80 grams of protein, 77 grams of fats, and 262 grams of carbohydrates daily (Raatz et al., 2017). Shan et al. (2019) estimated the energy contribution of macronutrients in a similar population and found that the share of proteins was $16.4 \%$, fats $-33.2 \%$, carbohydrates $-50.5 \%$. When assessing the nutrition of Canadians, the energy contribution of proteins was $16.5 \%$, fats - 31\%, carbohydrates - 50.1\% (Garriguet, 2007). In a study in South Africa, the contribution to the energy value of adult diets was $11-$ $18 \%$ of proteins, $17-37 \%$ of fats, and $47-69 \%$ of carbohydrates (Mchiza et al., 2015). Similar results were obtained in the UK: the share of proteins was $17 \%$, fats $36 \%$, carbohydrates - 47\% (Scarborough et al., 2016), as well as in Denmark and Finland: the contribution of proteins was $18.4 \%$ and $16 \%$, fats $-36.7 \%$ and $35 \%$, carbohydrates $-45 \%$ and $44.5 \%$, respectively (Jakobsen et al., 2015; Ahola et al., 2017). Similar data were obtained in Australia: pregnant women consumed 19.1\% of their energy from protein, 37.6\% from fat, and $41.5 \%$ from carbohydrates (Blumfield et al., 2015). In a study by George et al. (2018) the proportion of fats in the total calorie content of the diet was greater than the proportion of carbohydrates, which was not previously encountered.

In 2018, Chinese authors evaluated the energy value of the diets of people in the countryside and cities of China. In rural areas, the contribution to protein-calorie content was $13 \%$, fats $-32 \%$, carbohydrates $-55 \%$. In large cities, the share of proteins, fats, and carbohydrates in the total calorie intake was already $16 \%, 37 \%$, and $47 \%$, respectively (Yu, Lopez-Olmedo and Popkin, 2018). The results of this study, obtained in cities, are largely consonant with ours, while the nutrition of people from 
villages in China was more consistent with the standards recommended in Russia. In another study by Chinese authors, the energy contribution of proteins to the diet of the elderly was $12.3 \%$, fats $-30.8 \%$, carbohydrates $-56 \%$ (Xu et al., 2015), which is close to the data corresponding to eating behavior in the Chinese countryside. On the contrary, the nutrition of older people in Portugal was closer to the eating behavior of urban residents of China: $17.7 \%$ and $18.8 \%$ of calories consumed were provided by proteins in women and men, respectively, $34.6 \%$ and $34 \%$ - fats, $49.8 \%$ and $46.6 \%$ - carbohydrates (Santos et al., 2015). Bitok et al. (2017) assessed the consumption of macronutrients in elderly people from different countries. The number of proteins was 65 grams, fats -84 grams, carbohydrates - 204 grams, which is much less than our results. In Switzerland, by 2016, the consumption of proteins was 83.8 grams for men, 70 grams for women, fats -83.2 and 70.4 grams, carbohydrates -244 and 208 grams, respectively, which was also less than the values we obtained (Marques-Vidal et al., 2015).

In the study of R.B. Levy-Costa et al. (2005), it was observed that the nutrition of people in rural areas in Brazil was also more in line with the "Norms of physiological needs" than the results of our study: $12.8 \%$ of the calories were proteins, $27.6 \%$ were fats, and $59.6 \%$ were carbohydrates. An even smaller proportion of fats was in another study in South Africa. According to Kolahdooz, Spearing, and Sharma (2013), the share of proteins in the energy value of the diet was $11-13 \%$, fats $-18 \%$, carbohydrates $-67-69 \%$. A very low proportion of fat was also noted in a 2013 study in the United States. Approximately $18.2 \%$ of the total daily caloric content was ensured by protein intake, $11.4 \%$ from saturated fatty acids, and 67.7\% from carbohydrates (Huth et al., 2013). These results are similar to those obtained by Kolahdooz, Spearing and Sharma (2013), with the difference that the protein/fat ratio in South Africa was shifted towards the latter.

\section{Limitations of the study}

The efficiency of statistical data processing was decreased as a result of the fact that the quantitative composition of the groups varied greatly. For the same reason, as well as due to unequal gender composition, the groups were not divided by gender.

Another limitation of the study was the nutritional assessment method itself. Since the frequency analysis is based on the patient's subjective memories, the risk of accidental bias is relatively high. But still, in this case, the frequency method was preferable to the diary method, since nutrition was assessed over a rather long period and the transfer of the study from a cross-sectional format into perspective one would have been accompanied by the loss of a large number of subjects (if not all of them). Actually, in our particular case, the diary method was impossible at all, since the subjects' nutrition was assessed for the period before theyr arrival in Russia. It would be unacceptable to evaluate only the Russian group by the diary method within the framework of the methodological postulate of counteracting a systemic bias.

\section{CONCLUSION}

Even though the medians and the values of the $25^{\text {th }}$ and 75 th percentiles in the groups were significantly different, the huge variance of the indicators within each group did not reveal significant differences in the absolute consumption or contribution of any of the macronutrients to the total energy value of the diet between the groups. The exception was the difference in alcohol consumption and its share in total calories between students from the CIS countries and South and Equatorial Africa: the latter consumed significantly more ethanol-containing drinks, despite the prevailing stereotypes.

At the same time, we found that the consumption and ratio of macronutrients among residents of big cities of different countries have much greater similarities than between people living in cities and rural areas even within the same state.

The urban environment is likely to be crucial in shaping the diet of first-year students. Also, the results made us conclude that the nature of students' nutrition depends primarily on individual preferences, regardless of which camp the student came to Russia.

\section{REFERENCES}

Ahola, A. J., Harjutsalo, V., Thorm, L. M., Freese, R., Forsblom, C., Mäkimattila, S., Groop, P. H. 2017. The assosiation between macronutrient intake and the metabolic syndrome and its components in type 1 diabetes. Br. J. Nutr., vol. 117, no. 3, p. 450-456. https://doi.org/10.1017/S0007114517000198

Bitok, E., Jaceldo-Siegl, K., Rajaram, S., Serra-Mir, M., Roth, I., Feitas-Simoes, T., Ros, E., Sabate, J. 2017. Favorable nutrient intake and displacement with long-term walnut supplementation among elderly: results of a randomised trial. Br. J. Nutr., vol. 118, no. 3, p. 201-209. https://doi.org/10.1017/S0007114517001957

Blumfield, M. L., Nowson, C., Hure, A. J., Smith, R., Simpson, S. J., Raubenheimer, D., MacDonald-Wicks, L., Collins, C. E. 2015. Lowe protein-to-carbohydrate ratio in maternal diet is associated with higher childhood systolic blood pressure up to age four years. Nutrients, vol. 7, no. 5, p. 3078-3093. https://doi.org/10.3390/nu7053078

Galchenko, A. V., Morozova, L. D., Zaletova, T. S. 2017. Evaluation of protein and amino acid requirements, based on biosynthetic needs and nitrogen balance parameters. Nutrition, vol. 7, no. 2, p. 64-68. (in Russian)

Garriguet, D. 2007. Canadians' eating habits. Health Reports, vol. 18, no. 2, p. 17-32.

George, E. S., Kucianski, T., Mayr, H. L., Moschonis, G., Tierney, A. C., Itsiopoulos, C. 2018. A Mediterranean diet model in Australia: strategies for translating the traditional Mediterranean diet into a multicultural settings. Nutrients, vol. 10, no. 4, p. 465. https://doi.org/10.3390/nu10040465

Huth, P. J., Fulgoni, V. L., Keast, D. R., Park, K., Auestad, N. 2013. Major food sources of calories, added sugars, and saturated fat and their contribution to essential nutrient intakes in the U.S. diet: data from the National Health and Nutrition Examination Survey (2003-2006). Nutrition Journal, 12:116. https://doi.org/10.1186/1475-2891-12-116

Chemical Encyclopedia. 1999. Moscow, USSR : Soviet encyclopedias, vol. 5, 501 p. ISBN 5-85270-310-9. (in Russian)

Jakobsen, M. U., Madsen, L., Dethlefsen, C., Due, K. M., Halkjær, J., Sørensen, T. I. A., Kristiansen, K., Overvad, K. 2015. Dietary n-6 PUFA, carbohydrate: protein ratio and 
change in body weight and waist circumference: a follow-up study. Public Health Nutr., vol. 18, no. 7, p. 1317-1323. https://10.1017/S1368980014001578

Kolahdooz, F., Spearing, K., Sharma, S. 2013. Dietary adequacies among South African adults in Rural KwaZuluNatal. Plos ONE, vol. 8, no. 6, p. e67184. https://doi.org/10.1371/journal.pone.0067184

Kolman, J., Rum, K. G. 2000. Visual Biochemestry, Moscow, Russia : Mir, p. 312-313. (in Russian)

Levy-Costa, R. B., Sichieri, R., Dos Santos Pontes, N., Monteiro, C. A. 2005. Household food availability in Brazil: distribution and trends (1974-2003). Rev. Saude Publica, vol. 39 , no. 4, p. 530-540. https://doi.org/10.1590/s0034$\underline{89102005000400003}$

Lopez-Sobaler, A. M., Aparicio, A., Rubio, J., Marcos, V., Sanchidrian, R., Santos, S., Perez-Farinos, N., Dal-Re, M. A., Villar-Villalba, C., Yusta-Boyo, M., Robledo, T., CastrodezaSanz, J. J., Ortega, R. M. 2019. Adequacy of usual macronutrient intake and macronutrient distribution in children and adolescents in Spain: A National Dietary Survey on the Child and Adolescent Population, ENALIA 20132014. Eur. J. Nutr., vol. 58, no. 2, p. 705-719. https://doi.org/10.1007/s00394-018-1676-3

Madrigal, C., Soto-Mendez, M. J., Hernandez-Ruiz, A., Valero, T., Avila, J. M., Ruiz, E., Villoslada, F. L., Leis, R., de Victoria, E. M., Moreno, J. M., Ortega, R. M., Ruiz-Lopez, M. D., Varela-Moreiras, G., Gil, A. 2020. Energy intake, macronutrient profile and food sources of Spanish children aged one to $<10$ years - results from the EsNuPl Study. Nutrients, vol. $12, \quad$ no. $4, \quad$ p. 893. https://doi.org/10.3390/nu12040893

Marques-Vidal, P., Rousi, E., Paccaud, F., Gaspoz, J.-M., Theler, J.-M., Bochud, M., Stringhini, S., Guessous, I. 2015. Dietary intake according to gender and education: a twentyyear trend in a Swiss adult population. Nutrients, vol. 7, no. 11, p. 9558-9572. https://doi.org/10.3390/nu7115481

Martinez, S. M., Tschann, J. M., Butte, N. F., Gregorich, S. E., Penilla, C., Flores, E., Greenspan, L. C., Pasch, L. A., Deardorff, J. 2017. Short sleep duration is associated with eating more carbohydrates and less dietary fat in Mexican American Children. Sleep, vol. 40, no. 2, p. zsw057. https://doi.org/10.1093/sleep/zsw057

Matthys, C., De Henauw, S., Devos, C., De Backer, G. 2003. Estimated energy intake, macronutrient intake and meal pattern of Flemish adolescents. European Journal of Clinical Nutrition, vol. 57, no. 2, p. 366-375. https://doi.org/10.1038/sj.ejcn.1601533

Merkiel, S., Chalcarz, W. 2016. The need for modifying energy intake in preschool children from Pila, Poland. Rocz Panstw Zakl Hig, vol. 67, no. 2, p. 179-188.

Mchiza, Z. J., Steyn, N. P., Hill, J., Kruger, A., Schonfeldt, H., Nel, J., Wentzel-Viljoen, E. 2015. A review of dietary surveys in the adult South African population from 2000 to 2015. Nutrients, vol. 7, no. 9, p. 8227-8250. https://doi.org/10.3390/nu7095389

Norms of physiological needs. 2009a. Norms of physiological needs for energy and nutrients for various groups of the population of the Russian Federation. Nutritional Guidelines. Moscow, Russia : Federal Center for Hygiene and Epidemiology of Rospotrebnadzor, p. 30-36 (in Russian).

Norms of physiological needs. 2009b. Norms of physiological needs for energy and nutrients for various groups of the population of the Russian Federation. Nutritional Guidelines. Moscow, Russia : Federal Center for
Hygiene and Epidemiology of Rospotrebnadzor, p. 14-16. (in Russian).

Raatz, S. K., Conrad, Z., Johnson, L. K., Picklo, M. J., Jahns, L. 2017. Relationship of the reported intakes of fat and fatty acids to body weight in US adults. Nutrients, vol. 9, no. 5, p. 438. https://doi.org/10.3390/nu9050438

Rustan, A. C., Drevon, C. A. 2005. Fatty acids: structures and properties. Encyclopedia of Life Sciences. https://doi.org/10.1038/npg.els.0003894

Santos, D. M., Rodrigues, S. S. P., Oliveira, B. M. P. M., de Almeida, M. D. V. 2015. Dietary availability in elderly Portuguese household. Public Health Nutr., vol. 18, no. 3, p. 392-402. https://doi.org/10.1017/S1368980014000494

Scarborough, P., Kaur, A., Cobiac, L., Owens, P., Parlesak, A., Sweeney, K., Rayner, M. 2016. Eatwell Guide: modelling the dietary and cost implications of incorporating new sugar and fibre guidelines. BMJ Open, vol. 6, no. 12, p. e013182. https://doi.org/10.1136/bmjopen-2016-013182

Severin, E. S. 2011a. Biological chemistry: textbook. Moscow, Russia : GEOTAR-Media, 408-410 p. (in Russian)

Severin, E. S. 2011b. Biological chemistry: textbook. Moscow, Russia : GEOTAR-Media, 329-331 p. (in Russian)

Severin, E. S. 2011c. Biological chemistry: textbook. Moscow, Russia : GEOTAR-Media, 236-300 p. (in Russian)

Severin, E. S. 2011d. Biological chemistry: textbook. Moscow, Russia : GEOTAR-Media, 559-560 p. (in Russian)

Shan, Z., Rehm, C. D., Rogers, G., Ruan, M., Wang, D. D., Hu, F. B., Mozaffarian, D., Zhang, F. F., Bhupathiraju, S. N. 2019. Trends in dietary carbohydrate, protein, and fat intake and diet quality among US adults, 1999-2016. JAMA, vol. 322, no. $12, \quad$ p. $1178-1187$. https://doi.org/10.1001/jama.2019.13771

Tutelyan, V. A. 2012. The chemical composition and caloric content of Russian food: a Handbook. Moscow, Russia : DeLi plus. (in Russian)

Wakil, S. J. 1962. Lipid metabolism. Annual Review of Biochemistry, vol. 31, no. 1, p. 396-406. https://doi.org/10.1146/annurev.bi.31.070162.002101

Xu, X., Byles, J. E., Shi, Z., Hall, J. J. 2015. Evaluation of older Chinese people's macronutrient intake status: results from the China Health and Nutrition Survey. Br J Nutr, vol. 113 , no. 1, p. 159-171. https://doi.org/10.1017/S0007114514003444

Yu, A. Y. L., Lopez-Olmedo, N., Popkin, B. M. 2018. Analysis of dietary trends in Chinese adolescents from 1991 to 2011. Asia Pacific Journal of Clinical Nutrition, vol. 27, no. 5, p. 1106-1119. https://doi.org/10.6133/apjcn.042018.02

\section{Funds:}

The publication was prepared with the support of the RUDN university program $5-100$.

\section{Conflict of interests:}

The authors declare no conflict of interest.

\section{Contact address:}

*Alexey Galchenko, Federal Research Centre of Nutrition, Biotechnology and Food Safety, Kashirskoe sh., 21, 115446, Moscow, Russian Federation;

Peoples' Friendship University of Russia, Department of Medical Elementology, Miklukho-Maklay St., 6, 117198, Moscow, Russian Federation, Tel.: +79031991838,

E-mail: gav.jina@gmail.com

ORCID: https://orcid.org/0000-0001-7286-5044 
Elizaveta Sidorova, First Moscow State Medical University (Sechenov University), Trubeckaya st., 8s2, 119991, Moscow, Russian Federation, Tel.: +79199644072 ,

E-mail: sidorova e i@student.sechenov.ru

ORCID: https://orcid.org/0000-0003-3361-2460

Artem Barinov, Peoples' Friendship University of Russia, Medical Faculty, Miklukho-Maklay Street, 6, 117198, Moscow, Russian Federation,

E-mail: a.grindman@gmail.com

ORCID: https://orcid.org/0000-0003-0363-815X
Nikita Titiov, Peoples` Friendship University of Russia, Medical Faculty, Miklukho-Maklay Street, 6, 117198, Moscow, Russian Federation,

E-mail: tit-1996@yandex.ru

Andrew Skalny, Peoples' Friendship University of Russia, Department of medical elementology, MiklukhoMaklay St., 6, 117198, Moscow, Russian Federation, E-mail: skalny.pruf@yandex.ru

ORCID: https://orcid.org/56058947100

Corresponding author: * 